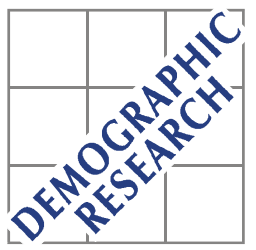

Demographic Research a free, expedited, online journal of peer-reviewed research and commentary in the population sciences published by the Max Planck Institute for Demographic Research Konrad-Zuse Str. 1, D-18057 Rostock · GERMANY www.demographic-research.org

DEMOGRAPHIC RESEARCH

VOLUME 25, ARTICLE 13, PAGES 437-464

PUBLISHED 12 AUGUST 2011

http://www.demographic-research.org/Volumes/Vol25/13/

DOI: 10.4054/DemRes.2011.25.13

Research Article

\title{
Who fears and who welcomes population decline?
}

\section{Hendrik P. van Dalen}

\section{Kène Henkens}

(C) 2011 Hendrik P. van Dalen \& Kène Henkens.

This open-access work is published under the terms of the Creative Commons Attribution NonCommercial License 2.0 Germany, which permits use, reproduction \& distribution in any medium for non-commercial purposes, provided the original author(s) and source are given credit.

See http:// creativecommons.org/licenses/by-nc/2.0/de/ 


\section{Table of Contents}

$1 \quad$ Introduction $\quad 438$

2 Population decline: Stylized facts and forecasts 440

$3 \quad$ Population decline and theory 444

$3.1 \quad$ Negative consequences of decline 444

$\begin{array}{lll}3.2 & \text { Positive consequences of decline } & 447\end{array}$

3.3 The tension between immigration and population decline 448

$4 \quad$ Data and method $\quad 449$

$5 \quad$ Explaining population size preferences $\quad 451$

$\begin{array}{lll}6 & \text { Conclusion and discussion } & 457\end{array}$

7 Acknowledgements $\quad 459$

$\begin{array}{ll}\text { References } & 460\end{array}$

Appendix: Properties of scale variables 463 


\title{
Who fears and who welcomes population decline?
}

\author{
Hendrik P. van Dalen ${ }^{1}$ \\ Kène Henkens ${ }^{2}$
}

\begin{abstract}
European countries are experiencing population decline, and the tacit assumption in most analyses is that this decline may have detrimental effects on welfare. In this paper, we use a survey conducted in the Netherlands to find out whether population decline is always met with fear. A number of results stand out. Population size preferences differ by geographic proximity, as the majority of respondents favor a decline in the global population, but support a stationary population closer to home. Population decline is clearly not always met with fear: $31 \%$ of respondents would like the population to decline at the national level, and they generally perceive decline to be accompanied by non-material welfare gains (improved environment), as well as material welfare losses (tax increases, economic stagnation). In addition to these driving forces, it appears that attitudes toward immigrants are very strong determinants of views regarding population growth at the local and the national levels. Immigrants seem to inspire greater fear than the prospect of population decline.
\end{abstract}

\footnotetext{
${ }^{1}$ Netherlands Interdisciplinary Demographic Institute (NIDI), P.O. Box 11650, NL-2502 AR The Hague, The Netherlands. Tilburg University, Department of Economics and Center, P.O. Box 90153, NL-5000 LE Tilburg, The Netherlands. Tel: +3170-3565235. Fax: +3170-3647187. E-mail: dalen@nidi.nl.

${ }^{2}$ Netherlands Interdisciplinary Demographic Institute (NIDI), P.O. Box 11650, NL-2502 AR The Hague, The Netherlands. Tilburg University, Department of Sociology, P.O. Box 90153, NL-5000 LE Tilburg, The Netherlands.
} 
van Dalen \& Henkens: Who fears and who welcomes population decline?

\section{Introduction}

The threat of population decline is not unique in demographic history, and has always been accompanied by stories of doom and gloom. During the first half of the 20th century, the decline in fertility and the quality of children were matters of public debate in many Western European countries (cf. Wicksell 1914; Keynes 1937). Current trends in fertility and mortality indicate that all developed countries have to reckon with the possibility of population decline, although the United States and New Zealand seem to be the exceptions to the rule. In all countries witnessing population decline, concerns have also been voiced about the loss of national identity because of lowered fertility and increased immigration (Teitelbaum and Winter 1998). France offers perhaps the clearest example within Europe of this attitude: former president Giscard d'Estaing stated his opposition to abortion, and said in a speech that "a society no longer capable of assuring the replacement of generations is a condemned society" (cited in Teitelbaum and Winter 1985:122).

A striking element in the debate about population decline is that it is dominated by concerned politicians, local government officials, academics, and journalists who are always on the lookout for "a good doom story." 3 For example, Newsweek published an article on the "Birth Dearth" in 2004, in which it claimed that the "new threat to the planet is not too many people but too few" (Newsweek, September 27, 2004). The citizens who have to live in regions or towns threatened by population decline are conspicuously absent in this debate. This is an unfortunate omission, because the quality of living arrangements is an important determinant of local voting behavior. Citizens can vote by casting a ballot in elections, or, if they lose their faith in government, they may vote with their feet by migrating to regions or countries where life still seems good (van Dalen and Henkens 2007). Under such circumstances, migration can reinforce population decline developments.

In this article, we examine the population size preferences of the Dutch population and its main determinants. The research question is threefold. First, what are the population size preferences of Dutch citizens concerning the population level of their place of residence and at the country level? Second, how can these preferences be explained? And third, how strong is the support for population-increasing policies?

A perspective on the Netherlands is interesting for a number of reasons. Demographic projections of Statistics Netherlands show that, in 2025, more than onehalf of Dutch municipalities will experience population decline. This development has provoked great concern among local governments, and makes for alarmist messages in

\footnotetext{
${ }^{3}$ Stark and Kohler (2002) have also pointed out how the popular press has a tendency to stress the negative consequences of low fertility, despite the fact that "many of the causes of low fertility are associated with social and economic progress" (p. 535).
} 
national newspapers. The following are some examples of the types of messages that are appearing in the media: "Shrinking towns should not become ghettos for senior citizens," "Cities are ill-prepared for population decline," and "The better educated are having too few children." In short, population decline is slowly but gradually becoming part of the Dutch reality, and in some regions it is already a fact of life (see Haartsen and Venhorst 2010).

Second, the Netherlands is one of the most crowded and urbanized nations in the planet. This high population density would seem to make the Dutch sensitive to issues of population size and structure. In fact, the feeling that the country is "overpopulated" has been among the main drivers of emigration of Dutch natives in recent years (van Dalen and Henkens 2007).

One of the elements of the debate on population decline is that the geographical perspective is either unclear, or it is not consistently applied by citizens and politicians (cf. Teitelbaum and Winter (1985), who also point out this issue). Discussions sometimes focus on the global level, with commentators suggesting that the growth in the world's population exceeds the carrying capacity of the earth. Other debates center on individual countries, regions, or cities. In addition letting the people speak, and not the authorities, in this paper we seek to disentangle the population size preferences of the Dutch for different geographical perspectives that seem to play a role in population debates. We will study the differences in attitudes toward population decrease or increase at the levels of the place of residence, the country, and the world. To capture population preferences and underlying attitudes toward population growth, we developed a survey that was carried out in 2009 among the Dutch population. In the survey, population size preferences, as well as the expected consequences of population decline, were measured at different regional levels.

The structure of this paper is as follows. In Section 2 we will elaborate on the Dutch context. In Section 3 we look at the theories that shed light on the consequences of population decline, and we formulate our main hypotheses regarding population size preferences. Section 4 presents the data and methods used to test the hypotheses. We continue in Section 5 with a presentation of the results of multivariate analyses that examined the question of why some people support, and others oppose declining populations. Section 6 concludes with a summary of the main findings and a discussion. 


\section{Population decline: Stylized facts and forecasts}

In this paper, we will focus on the Dutch case, which embodies a number of demographic characteristics that are shared by numerous Western European countries. But the Netherlands also represents a case that incorporates unique elements that are often left out of population analyses.

We will start by describing the demographic elements that the Netherlands has in common with other European countries. Based on Eurostat forecasts, Figure 1 presents the population changes that are expected to occur in European regions. The population in the entire region (EU27 plus Norway and Switzerland) is expected to grow from 508 million in 2008 to 534 million in 2030. Because of fewer births (due to belowreplacement fertility and smaller cohorts of women reaching reproductive age) and more deaths (due to population aging), the number of regions with more deaths than births is expected to rise from 131 in 2008 to 207 in 2030. However, for some regions the natural decrease is compensated by migration flows; hence, reductions in population numbers are predicted for almost 100 regions. Most of these regions can be found in Bulgaria, the Czech Republic, Germany, Hungary, Poland, Romania, and Slovakia. Spain, Greece, and Italy also have several regions with projected population declines. A decrease of more than $20 \%$ is anticipated for Severozapaden (Bulgaria) and the German regions of Chemnitz, Saxony-Anhalt, Dresden, and Thuringia. Such a large drop is not foreseen for the Netherlands in this period, as the onset of the decline in the country lags considerably behind the beginnings of the downward trends in these regions. The Dutch demographic future is, however, characterized by falling population numbers: recent population forecasts suggest that, at the aggregate level, the Dutch population will slowly begin to decrease at a national level around 2040 (Van Duin and Garssen 2011).

Behind the aggregate demographic statistics emerges the picture of a divide between the populous Dutch west ("Randstad"), which will in all likelihood experience some further increases in population size and density, and the remaining, more rural regions that will experience - and are already strongly experiencing-population declines. Figure 2 clearly illustrates how the Netherlands is a mixture of regions with population growth and population decreases (De Jong and Garssen 2009). 
Figure 1: Population change (in growth rates) between 2008 and 2030, NUTS2 regions
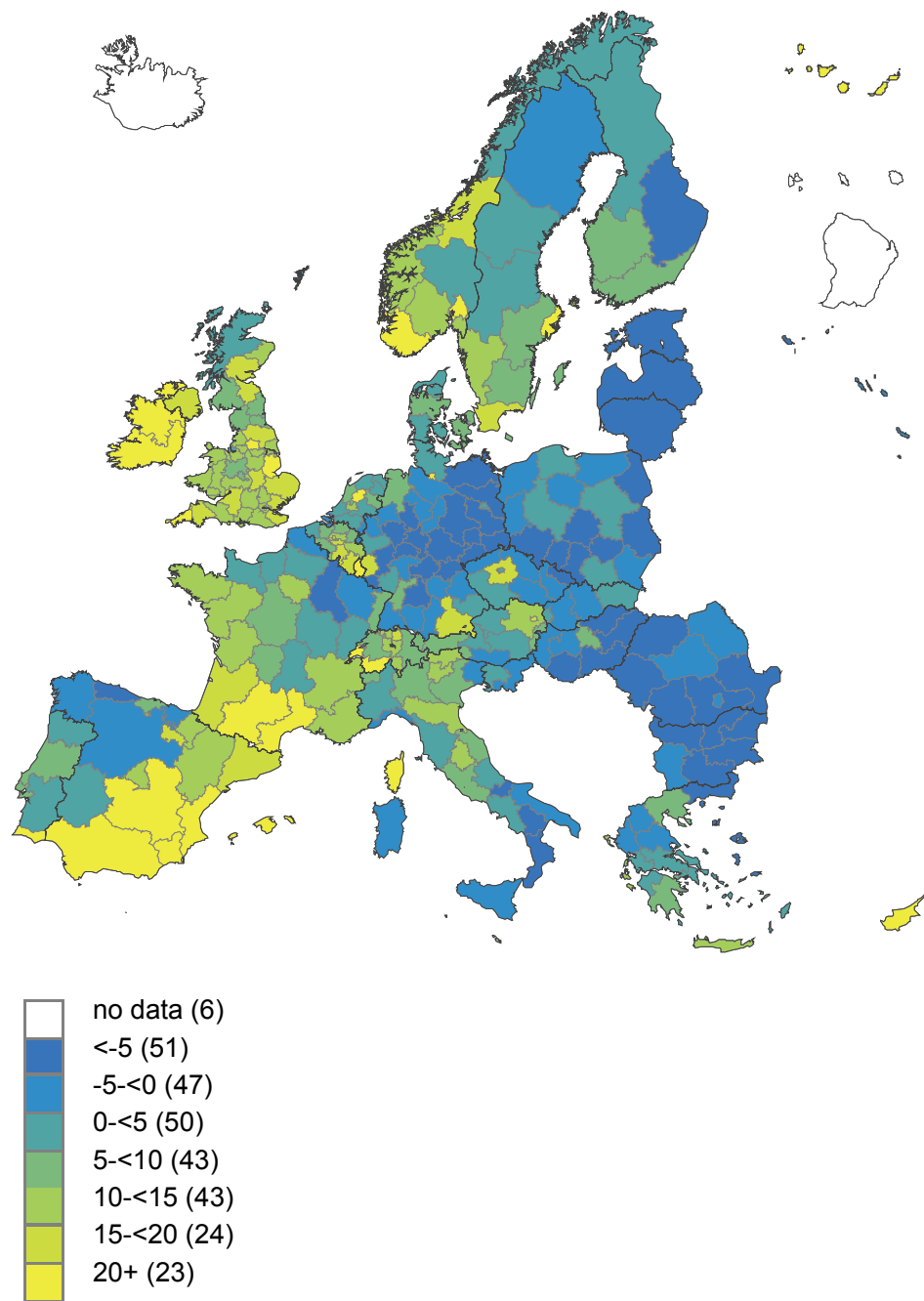

Source: EUROSTAT. 
van Dalen \& Henkens: Who fears and who welcomes population decline?

Figure 2: Population change (in growth rates) at the municipality level between 2007 and 2025, The Netherlands

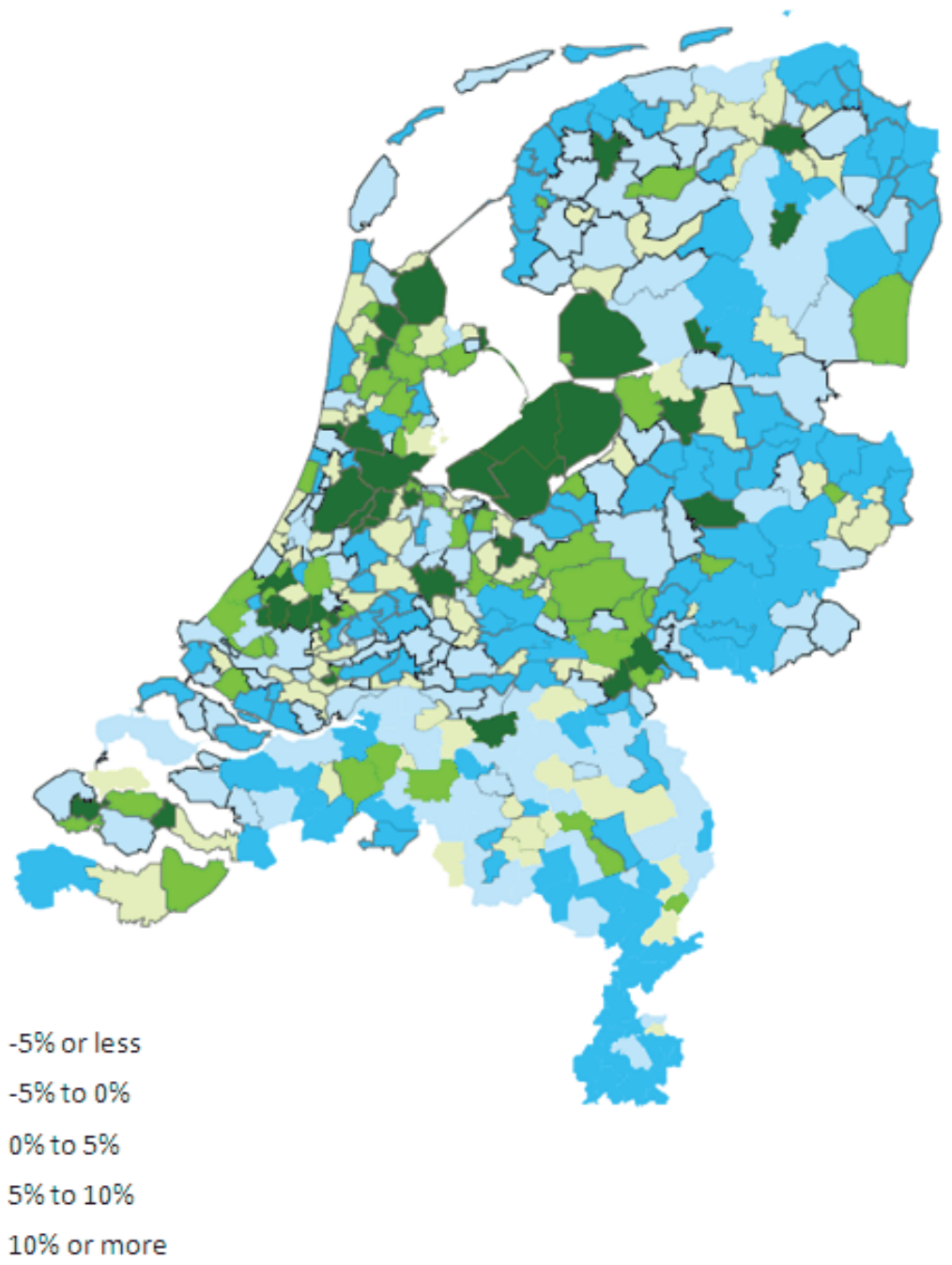

Source: CBS Statline. 
For these reasons, the Dutch government is slowly but steadily changing its course from not interfering in matters of population, to taking a coordinating role in balancing the pressures of population growth in urban regions against the prospect of population decline in rural regions. In short, the Netherlands provides us with a case study in how the state deals with opposing demographic forces - a challenge that is likely to arise throughout the European Union, which is marked by depressed regions facing depopulation, and prosperous regions that are still experiencing growth. In addition to its population growth diversity, the Netherlands is similar to the rest of Europe in other respects as well. For example, total fertility rates in the country are below replacement level (1.7), although this level does not yet concern most government officials. ${ }^{4}$ Active government involvement in matters of fertility is absent, although members of parliament are constantly pleading for a policy to make it easier for people to combine work and family. Employers are concerned about the labor market consequences of population decline, but when it comes to counteracting this development, the large majority of Dutch employers do not support pronatalistic policies, and mainly seek economic solutions (see van Dalen et al. 2010).

Immigration is also a hotly debated issue in the Netherlands, as the percentage of foreigners who live in the country is substantial by European standards $(13 \%$ of the total population), and immigrants of non-Western origin are met with particular skepticism or even outright hostility. The weak integration of non-Western immigrants is generally seen as a failure, and the general attitude of the government toward immigration is one of restraining inflow.

In addition to these common elements, the Dutch case may be of considerable interest as it has some unique features that are not yet present in other countries. At the time of the survey, the Netherlands was, with 484 citizens per square kilometer, one of the most crowded countries of the EU, ${ }^{5}$ followed by Belgium ( 351 people per $\mathrm{km}^{2}$ ) and the UK $\left(251\right.$ per $\left.\mathrm{km}^{2}\right)$. If we do not consider the world's island states and city states, we could even say that it is one of the most crowded countries in the world — only South Korea is more densely populated, with 492 citizens per $\mathrm{km}^{2}$. The Dutch may therefore see not only the negative sides of population decline but also the positive consequences. As in other countries, the Netherlands has a pressure group that favors population decline: the "Club of Ten Million" advocates a population decrease, as long as the Dutch population remains larger than what it considers the optimal number of 10

\footnotetext{
${ }^{4}$ There are, of course, exceptions to this rule, as illustrated by a recent event. The Christian minister André Rouvoet aired the opinion in the Dutch newspaper De Pers (February 18, 2008) that it would be good idea to have a discussion about population policy in light of the rising costs of aging. His ideal fertility level for coping with the consequences of aging would be 2.1. Even though he stated that he was not in favor of a pronatalistic population policy, his suggestion sparked off a lively debate in which most politicians expressed their disgust about this "faux pas" of a cabinet member.

${ }^{5}$ If Malta is not taken into account, then it is the most densely populated country of the EU.
} 
million inhabitants (it currently is 16.5 million inhabitants). Population density matters for Dutch government policy because access to public services and public goods are hampered by congestion effects, with traffic congestion being the most obvious problem. But congestion is also challenge in questions of health care, public transport, parking, schooling, social housing, and the use of public forests, or in issues concerning the environment in general. Indeed, the Netherlands has a long history of concern about the consequences of overpopulation. This was one of the big policy issues that was debated by Dutch citizens and politicians in the years following the Second World War. It even led some politicians in the 1950s - notably, Prime Minister Drees - to urge the Dutch to leave their country (van Dalen and Henkens 2007). Overpopulation was then seen as one of the driving forces behind long-term unemployment and housing shortages. Over time, the Dutch appear to have learned to cope with the consequences of a densely populated country, as the promotion of emigration has faded away. However, the level of (spatial) regulation has become of paramount importance in the Netherlands, as virtually every individual action is accompanied by external effects. The government seeks to address the consequences of a high population density by means of rules and regulations, and, wherever possible, through the use of price mechanisms that encourage the most efficient use of services and goods within the public domain.

\section{Population decline and theory}

Economic and demographic theory do not offer an unambiguous prediction regarding the consequences of population decline. The debate among scholars is marked by optimists and pessimists regarding the prospect of population decline. We will not review the entire literature and history surrounding the issue of decline (see Coleman and Rowthorn (2011) for a more detailed discussion of that point, and Teitelbaum and Winter 1985, 1998), but we will briefly highlight the main theoretical strands, and use these insights as a guide to understanding how people make their assessments.

\subsection{Negative consequences of decline}

The ways in which population declines can have negative consequences can be reduced to three important transmission mechanisms.

The first mechanism refers to the connection between public finance and population size, at both the local and national levels. The prospect of population decline can be of considerable importance for an extensive welfare state, as pensions and social 
security are usually financed on a pay-as-you-go basis; such a method works well in the face of an expanding population, but the financial basis may become unsustainable when the decline is rapid and prolonged. ${ }^{6}$ For example, pure public goods and services can be more easily financed when the relevant population is growing. The logic behind this public sector calculus is fairly straightforward: the average tax burden for the provision for a public good can be spread over more people. National defense or a dyke are examples pure public goods: i.e., goods for which it is neither feasible nor desirable to ration their use (Stiglitz 2000). Once the decision has been made to build a dyke and a certain threshold has been surpassed, the financing of the public good is easier when the tax base covers 200,000 instead of 100,000 citizens. A decline in the population may therefore be accompanied by negative consequences because (1) the tax base decreases, but if government expenditures are fixed or slow to adjust, deficits accumulate, and tax rates will eventually have to rise; and (2) if certain population levels are needed to finance public goods (e.g., schools, hospitals, public transport) that are essential for a community to function, and the population drops below these thresholds, the process of depopulation may speed up. Both of these elements are relevant for understanding the consequences for public finances of a shift from a growing to a declining population. If a population is growing based on an upswing in fertility, the population will be relatively young, and a country or region will benefit from the fact that a young population generates more net benefits than an aging population. Geys, Heinemann, and Kalb (2008) show for a sample of 1,021 German municipalities how smaller municipalities (fewer than 6,000 inhabitants) in particular are vulnerable to increasing cost pressures resulting from population declines.

Of course, a nation or region experiencing a population decline need not experience in increase in tax rates if the relevant government adapts to changing circumstances, and brings the level of public expenditures in line with the tax base. The problems start mounting when communities or cities do not adapt, clinging to the old level of expenditures, even as tax income drops along with the decline in population, and these shortfalls can only be countered by raising tax rates. In other cases local governments may refuse to face up to a probable future of decline and start a "race to the bottom" by trying to attract people from other regions or countries. Some Dutch cities (notably in the regions experiencing population decline) have tried the strategy of offering lower tax rates or higher service levels, but in general most come to realize that this is a zero-sum game: alleviating the problems of one city exacerbates the problems of a neighboring one.

\footnotetext{
${ }^{6}$ To illustrate the size of the compensating demographic measures that might be required, Bongaarts (2004) has shown that a $10 \%$ reduction in public pension expenditures might obviously be established by cutting benefits by $10 \%$. However, the same objective might be achieved by raising the total fertility rate (permanently) by 0.3 , or by increasing (again permanently) the immigration rate by 1.8 immigrants per 1,000 inhabitants.
} 
van Dalen \& Henkens: Who fears and who welcomes population decline?

A second mechanism by which population size affects the economy is when the population size or density influences the relative price of a good or service or factor supplies (capital, labor, land). A source of particular concern to most citizens in developed countries is the price of housing. If a population decline leads to a decrease in housing demand, and the housing supply remains fixed, then falling prices may be the result. This relationship may be perceived as a decline in welfare, as housing wealth makes up a large proportion of the total wealth of households (if they own a home). In short, the consequences of a population decline for home owners depend in large part how the housing market functions, as the supply of housing reacts only very slowly to changes in demand, whereas demand is closely tied to the age structure of a population (Mankiw and Weil 1989). A baby boom can therefore lead to a strong rise in housing prices with a considerable time lag, as potential (first-time) home buyers are usually in the 25-40 age range. The opposite can also occur when the boom is followed by a bust, although the reaction may be asymmetric, as the housing supply will adapt only very slowly to the decline in demand. Property owners are not apt to demolish their house and decrease the surplus of housing, as Eichholtz and Lindenthal (2007) suggest. It is more likely that a population decline will reveal itself in the proliferation of vacant dwellings, lower housing prices, and a limited transaction volume of houses bought and sold. Of course, whether a person perceives the consequences of population decline for the housing market to be negative depends on whether he or she owns a house. It may very well be the case that young people who have yet to enter the housing market may see the advent of population decline as a blessing. Like in other European countries, the Dutch housing market is unbalanced, with real estate prices that skyrocketed during the 1990s, when younger generations in the Netherlands financed their (first) home purchases entirely through mortgages, rather than through private savings.

A third mechanism that is often stressed in economic theory is the link between economies of scale, population size or density, and technical progress. The power of cities is that they internalize the externalities that are tied to a number of markets essential for the progress of cities. Many noted authors have made this link, including Marshall (1920), Jacobs (1969), Lucas (1988), Krugman (1991, 1998), and Glaeser (1998). Population growth may serve as a stimulant for technical progress and entrepreneurial activity. The fear of city councils of a decline in the local population is therefore understandable. Outmigration flows may signal to potential entrepreneurs and citizens that a specific urban agglomeration is sliding into a phase of economic stagnation or decline.

Based on the different mechanisms that point to the negative consequences of population decline for the wealth of nations or cities, we formulate the materialism hypothesis: People who expect a reduction in population numbers to have adverse 
material consequences (e.g., an increase in taxes or a decrease in the provision of public goods) are less likely to prefer a decline in population.

\subsection{Positive consequences of decline}

Other theories point to the adverse consequences of overpopulation, and therefore assert that population decline may have a benign effect on economic welfare. There are two related strands of literature that argue for the benefits of declining population. Some proponents of this view have suggested that certain public goods are not as positive as the economic textbooks would suggest, and give rise to congestion in use. Infrastructure like highways or electrical power networks can be overutilized during rush hours, as an increase in the number of inhabitants leads to congestion. The link with population growth is not, however, cast in stone, because it presumes that every new or existing member of the population exhibits the same type of behavior.

A discussion of negative externalities can also be found in the literature, with some authors stressing that the growth in the world's population exceeds the carrying capacity of the earth. This mechanism relates to the Malthusian assertion that the earth's capacity to support mankind is outpaced by population growth. The main proponent of this view was Hardin (1968), who explained this idea more fully in his classic article, "Tragedy of the Commons." The logic of his argument relies on the presence of an impure public good: i.e., the commons. When it is impossible to limit use of this good, through either market forces or central planning, the commons will become overcrowded. This is what seems to be happening to the environment, and it is the central thesis behind Al Gore's documentary An Inconvenient Truth. Hardin related the tragedy directly to the problem of overpopulation, and his conclusion was therefore quite unequivocal: "Freedom to breed will bring ruin to us all" (1968:1248). The finiteness of natural resources and the presence of "the commons" in various domains of life may lead citizens to view population growth as exhibiting negative externalities. There are numerous political pressure groups in the international arena ${ }^{8}$ trying to establish zero or negative population growth in order to prevent a "tragedy of the commons."

Following this line of reasoning, we state the non-materialism hypothesis: People who expect population decline to improve the non-material living circumstances (better

\footnotetext{
${ }^{7}$ Hardin was not the first to examine the classic problem of the commons. For an overview of scholars who examined the commons problem, see Stavins (2011).

${ }^{8}$ See, for example, the program of the association Negative Population Growth (http://www.npg.org/), or the Dutch Club of Ten Million (http://www.tienmiljoen.nl/Eng/index.htm).
} 
van Dalen \& Henkens: Who fears and who welcomes population decline?

environmental quality, less population pressure, less noise pollution) are more likely to have a preference for population decline. ${ }^{9}$

\subsection{The tension between immigration and population decline}

A third issue that needs to be addressed refers to the composition of population growth or decline. Attitudes of citizens may differ according to the composition of population growth. People may be concerned about population decline, but may reject the opportunities that international migration provides for counteracting further decreases in the population. It is at this point that politics and demography intersect. Indeed, Teitelbaum and Winter (1998) have stressed the importance of studying the interaction between declining fertility, international migration, and national identity in developed countries jointly, and on a national basis. The prime reason for this national focus can be traced back to the experience that the nexus between fertility, migration, and identity "always reflects local histories, attitudes and interests." (Teitelbaum and Winter 1998:4) Immigration in particular evokes mixed emotions among politicians and the population at large. On the one hand, international migration offers employers access to a pool of labor supply that may mitigate labor market frictions. Under quite general assumptions, immigration also offers host countries a net welfare gain (Borjas 1995). On the other hand, most European countries have a hard time adapting to the status of being nations of immigrants, as the assimilation or integration of non-Western immigrants has not gone as smoothly and quickly as initially anticipated. Ethnic identities appear to be more persistent than was expected, and, as Bisin et al. (2011) have shown, immigrants with a strong ethnic identity (i.e., attachment to religion, cultural traditions, and language) do not fare well in European labor markets. Furthermore, distribution of the net welfare gain of immigration tends to be unevenly spread among the native population. Many studies have noted that the negative effects are concentrated in certain parts of the native population, such as the less educated (see van Dalen and Henkens 2005).

The rapid rise of political anti-immigration movements is a response to frustration and fear in a number of European countries: Austria (Freedom Party), France (National Front), Belgium (Vlaams Blok), Denmark (Danish People's Party), and Italy (Northern League). The Netherlands is no exception to this trend either, as the Dutch have witnessed the rise of a similar party (PVV or the Freedom Party), and party leader, Geert Wilders, whose political program is rather outspoken and negative about the

${ }^{9}$ We acknowledge that some of these non-material effects can have material effects (e.g., traffic jams can affect the number of hours worked, and less noise pollution leads to higher housing prices), but for the purposes of this paper, we focus on direct effects. 
admission of non-Western, Muslim migrants. Although members of this political party are quite articulate in expressing their opposition to expanded international migration, the support of immigration restrictions in the Netherlands is broad-based, including by parties in the center of the political spectrum and liberal parties. We predict that people who view the integration of immigrants negatively are more likely to prefer a decrease in the population than those who view this process positively (population composition hypothesis).

\section{Data and method}

To examine the population size and policy preferences of Dutch citizens and their perceptions about the consequences of population decline, we developed a questionnaire that was distributed among a representative sample of Dutch citizens. The survey was carried out in January 2009 by the institute CentER Data of Tilburg University. CentER Data maintains a nationwide panel of households in the Netherlands. The panel is representative of the Dutch population with respect to sex, age, education, religion, and regional variation. Respondents are interviewed mainly online, and for those who do not have access to the Internet, data are collected through a television Netbox system. ${ }^{10}$ As such, there is no selectivity with regard to whether people have Internet access or not. In general, people participate in the panel for about four years, and they are regularly interviewed on several topics over the course of this period. When a respondent leaves the panel, a new respondent is selected on the basis of socio-demographic characteristics, so that representativeness will be maintained. Respondents are on average 51.3 years old and $46 \%$ female. Approximately $11 \%$ of the respondents live in one of the provinces (Limburg and Zeeland) that have experienced population decline in the period 2000-2009 (see Table 1).

\footnotetext{
${ }^{10}$ Participants who do not have Internet access are provided with a special service by the institute CentERdata, which allows them to access the Internet through their televisions. Households that do not have a TV set are given one by CentERdata. For more information on the panel data, see http://www.centerdata.nl/ en/.
} 
van Dalen \& Henkens: Who fears and who welcomes population decline?

Table 1: Descriptive statistics

\begin{tabular}{|c|c|c|c|c|}
\hline Variables & Mean & SD & Min & Max \\
\hline Population preference, local & 2.05 & 0.52 & 1 & 3 \\
\hline Population preference, national & 2.25 & 0.55 & 1 & 3 \\
\hline Population preference, global & 2.49 & 0.55 & 1 & 3 \\
\hline Age (in years) & 51.3 & 16.0 & 16 & 93 \\
\hline Sex $(0=$ male, $1=$ female $)$ & 0.46 & 0.50 & 0 & 1 \\
\hline Educational level ( $1=$ low level to $6=$ high level) & 3.64 & 1.52 & 1 & 6 \\
\hline Income adequacy ( $1=$ with great difficulty to $4=$ very easy) & 2.88 & 0.70 & 1 & 4 \\
\hline Role of religion in life ( $1=$ very important to $4=$ not important at all) & 3.05 & 0.97 & 1 & 4 \\
\hline Local population density ( $1=$ very high to $5=$ very low $)$ & 2.96 & 1.31 & 1 & 5 \\
\hline Province of population decline during 2000-2009 (0= no) & 0.11 & 0.32 & 0 & 1 \\
\hline \multicolumn{5}{|l|}{ Expected consequences of population decline with respect to: } \\
\hline Local tax level & 3.50 & 0.67 & 1 & 5 \\
\hline Local public service level ${ }^{a}$ & 2.66 & 0.50 & 1 & 5 \\
\hline Space and nature, local level & 3.43 & 0.62 & 1 & 5 \\
\hline National tax level & 3.50 & 0.70 & 1 & 5 \\
\hline National economic growth potential ${ }^{a}$ & 2.99 & 0.54 & 1 & 5 \\
\hline Space and nature, national level & 3.52 & 0.68 & 1 & 5 \\
\hline Attitudes toward immigration ${ }^{a}$ & 2.81 & 0.79 & 1 & 5 \\
\hline Attitudes toward global warming ${ }^{a}$ & 3.24 & 0.68 & 1 & 5 \\
\hline
\end{tabular}

Sample N $=2035$.

(a): see Appendix for description of scale variables.

The population size preferences of the respondents are surveyed at three levels of aggregation: the population of the level of the local community, the population at the national level, and the population at the global level. People were asked to answer the following question: "Do you think that the number of [inhabitants in your place of residence] should increase, stay the same, or decrease?"11

To examine the variations in local and national population size preferences, we focus on the expected consequences of population decline at the corresponding local and national levels. We do not explain global preferences, as we presume this exercise is too difficult for citizens to grasp. Respondents are more likely to have more or less informed expectations and information on national and local circumstances. To evaluate the material consequences of population decline at the level of the place of residence, we introduce a variable measuring the expectations of people with respect to the local tax level. And to measure the expected material effects of population decline on the provision of public goods, we introduce a (scale) variable to capture the perception of public amenities (e.g., the number of shops and the level of services). A similar

${ }^{11}$ For the other geographic dimensions, the terms between brackets were replaced by "number of inhabitants in the Netherlands" and "number of people in the world," respectively. 
procedure is used to measure the public benefits of population decline at the national level, but this time the scale variable comprises the expected effects of population decline on economic growth and the level of innovation. The non-material consequences of population decline are represented by a variable measuring the expected consequences of the decline for open space and nature. The quality of the national environment is summarized by a question about the expected levels of open space and nature for the nation as a whole. Finally, we present two scale variables that relate to both global and national issues: attitudes regarding immigration and global warming. The complete list of scale variables and the underlying items are presented in the appendix to this paper, A1. Descriptive statistics for each of the different variables are presented in Table 1.

\section{Explaining population size preferences}

The first issue we would like to address is whether people favor a larger or a smaller population size. The overall answer is that population size preferences differ markedly depending on the geographical perspective of the respondents.

The majority of the Dutch are in favor of global population decline. We also asked respondents how large this preferred decline should be. The question posed was: "The current global population consists of 6.7 billion inhabitants. What is, in your opinion, a desirable population size?" The most common answer was five billion people, with the average preferred population number being 5.6 billion. In 2008, the world population was estimated to be 6.8 billion; hence, according to the Dutch, the global population should decrease by 1.2 billion persons.

The size of the group preferring a population decline decreases as the geographic focus moves closer to home: $31 \%$ of respondents said they want the population of the Netherlands to be smaller, but when the same question was asked about their local place of residence, only $16 \%$ said they are in favor of a decline in population. Most of the respondents said they prefer the status quo for their country and/or their place of residence. However, if researchers were to ask for a numeric evaluation of the desired population size, the Dutch would generally opt for a small population decline. The average desired population size is 15 million inhabitants, which is 1.5 million less than the current 16.5 million. 
Figure 3: $\quad$ Preferred population sizes at the global, national, and local (place of residence) levels, 2009

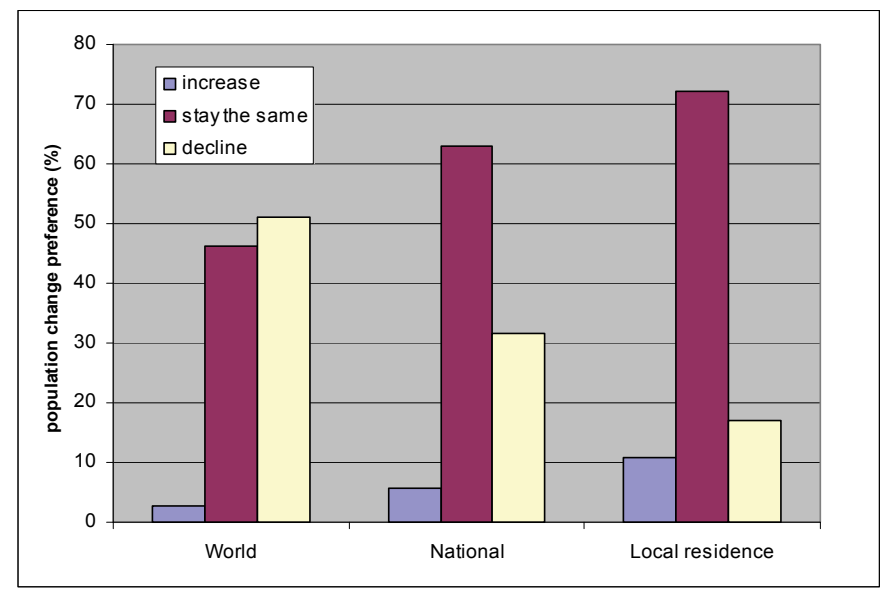

Source: NIDI survey on population decline (2009).

We tested the three hypotheses mentioned in the previous section using multinomial logit analysis. In doing so, we compared the supporters of either population decline or increase with those citizens who favor the status quo. We tested the hypotheses at two different levels. First, we examined the driving forces behind population size preferences at the national level, and then performed a comparable analysis at the local level (place of residence).

\section{Population size preferences at the national level}

Table 2 presents the multinomial logit analysis explaining population size preferences at the national level. The first column shows that supporters of a population decline are less pessimistic about its negative economic consequences, and are much more negative about the inflow and integration of immigrants than proponents of the status quo. Moreover, supporters of a population decline expect positive externalities from such a decline: in particular, environmental quality is expected to improve considerably. This conclusion holds for the perceived increase in open space and nature at the national level, but these supporters also perceive population decline as a force that can counter concerns about global warming. The non-materialism hypothesis is therefore an important force in explaining preferences for population decline at the national level.

The second column shows that the materialism hypothesis and the population composition hypothesis are supported when it comes to explaining preferences for a 
population increase. Proponents of a population increase can be found among those respondents who expect a decrease in population to have negative economic consequences (especially in terms of tax levels), and those who perceive net benefits from international migration. Interestingly, the non-materialism hypothesis is not supported in terms of preferences for population increase.

Close inspection of the groups supporting a decrease in the population reveals an odd political feature, as the supporters of a population decline are found at the extremes of the political spectrum. On the one hand, proponents of lower population numbers can be found among those who oppose international migration, and such supporters can be found mainly among right-wing voters. On the other hand, we find proponents of population decline among people who are concerned about the global environment and the preservation of open space and nature at the national level, and they can usually be found among left-wing voters. In short, population decline makes for strange bedfellows.

Table 2: Multinomial logit analysis explaining population size preferences of Dutch citizens at the country level $(\mathbf{N}=\mathbf{2 , 0 3 5})$, status quo $=$ base outcome

\begin{tabular}{|c|c|c|c|c|}
\hline \multirow{3}{*}{ Explanatory variables } & \multicolumn{4}{|c|}{$\begin{array}{l}\text { Population size preference } \\
\text { with respect to national population }\end{array}$} \\
\hline & \multicolumn{2}{|c|}{ Decline } & \multicolumn{2}{|c|}{ Increase } \\
\hline & Coefficient & $t$-value & Coefficient & $t$-value \\
\hline \multirow{2}{*}{\multicolumn{5}{|c|}{ Perceived consequences of population }} \\
\hline & \multicolumn{4}{|c|}{ decline on: } \\
\hline National tax level & $-0.47^{\star *}$ & 6.16 & $0.72^{* *}$ & 4.33 \\
\hline National economic growth potential & $0.34^{* *}$ & 3.32 & -0.16 & 0.89 \\
\hline National space and nature & $0.50^{* *}$ & 5.90 & -0.07 & 0.46 \\
\hline \multicolumn{5}{|l|}{ Attitudes toward: } \\
\hline Immigration & $-0.65^{\star *}$ & 8.84 & $0.27^{*}$ & 2.01 \\
\hline Global warming & $0.27^{\star *}$ & 3.47 & -0.18 & 1.32 \\
\hline \multicolumn{5}{|l|}{ Background variables } \\
\hline Age & 0.00 & 1.28 & 0.00 & 0.52 \\
\hline $\operatorname{Sex}($ male $=0)$ & -0.08 & 0.72 & $-0.68^{* *}$ & 3.27 \\
\hline Years of education & 0.04 & 1.18 & -0.06 & 0.91 \\
\hline Income adequacy & 0.05 & 0.61 & $-0.33^{*}$ & 2.32 \\
\hline Religiosity level & $0.15^{\star *}$ & 2.70 & 0.09 & 0.91 \\
\hline Population density, place of residence & -0.07 & 1.68 & $-0.16^{*}$ & 2.04 \\
\hline Province of decline $(\mathrm{no}=0)$ & $-0.62^{* *}$ & 3.29 & -0.20 & 0.65 \\
\hline Constant & $-1.99^{* *}$ & 2.81 & -2.21 & 1.65 \\
\hline Pseudo $\mathrm{R}^{2}$ & \multicolumn{4}{|c|}{0.10} \\
\hline
\end{tabular}

Note: Absolute $t$ values are stated in parentheses. * Significant at $p<0.05$. ${ }^{*}$ Significant at $p<0.01$. 
In Table 3 we present more descriptive statistics about the perceived consequences of population decline at the national level for three categories of respondents: supporters of a population increase, advocates of a stationary population, and supporters of a decline in population. The first column of this table shows that, on aggregate, the majority of respondents expect that a population decline would have negative economic consequences, as well as positive effects on the environment. The groups differ in the weight they assign to externalities. Whereas supporters of a population decline emphasize the positive externalities with respect to improvements in space and nature, $40 \%$ of them also expect - and apparently accept - the negative implications with respect to tax levels. Of those who support a population increase, the majority (79\%) expect tax increases as a result of a possible population decline. However, it is interesting to note that supporters of a population increase also seem to recognize the possible negative externalities of population growth with respect to the environment. Almost half $(45 \%)$ of respondents are aware that population decline will probably have beneficial effects on the quality of the natural environment, and will lead to increases in the amount of open space.

Table 3: Percentage in agreement with expected consequences of population decline at the national level, grouped by population size preference

\begin{tabular}{lcccc}
\hline & & \multicolumn{3}{c}{ Proponents of: } \\
\cline { 3 - 5 } Expected consequences of decline: & Total & Increase & Stationarity & Decline \\
\hline Increase in tax level & 55 & 79 & 60 & 40 \\
Increase in nature and space & 56 & 45 & 50 & 71 \\
Decrease in traffic congestion & 55 & 29 & 49 & 72 \\
Decrease in unemployment & 51 & 38 & 47 & 61 \\
Decrease in economic growth & 26 & 39 & 28 & 19 \\
Decrease in innovation potential & 13 & 29 & 14 & 9 \\
$\mathrm{~N}=$ & 2039 & 120 & 1288 & 632 \\
\hline
\end{tabular}

Source: NIDI survey on population decline (2009).

Population size preferences at the local level

Table 4 presents the results of the corresponding analysis of population size preferences at the level of place of residence. To a large extent, this analysis provides a similar picture to that found at the national level, with significant support for the population composition hypothesis and the non-materialism hypothesis. Those who favor local population decline have strong anti-immigration sentiments. The individual survey items suggest that fear of the "foreign" element is clearly present among the Dutch: approximately $52 \%$ of respondents agree with the statement: "The growth in the 
number of foreigners contributes to crime and terrorism."12 Supporters of population decline are also much more worried about the impact of population density on the environmental quality of their place of residence. With respect to preferences regarding population growth, the results provide support for the materialism hypothesis. In addition the positive effects of an increase in the population at the level of local taxes, it is clear that concerns about the level of local public services are also an important factor in explaining a preference for population growth. Citizens in favor of population growth at the local level are particularly worried about the possible negative externalities of population decline on the level of public amenities (e.g. schools, swimming pools) and the number of local shops. This factor does not seem to play a role in explaining preferences for population decline.

Table 4: $\quad$ Multinomial logit analysis explaining population size preferences with respect to place of residence $(\mathrm{N}=\mathbf{2 0 3 5})$, status quo $=$ base outcome

\begin{tabular}{|c|c|c|c|c|}
\hline \multirow{3}{*}{ Explanatory variables } & \multicolumn{4}{|c|}{$\begin{array}{c}\text { Population size preference } \\
\text { with respect to local population }\end{array}$} \\
\hline & \multicolumn{2}{|c|}{ Decreasing population } & \multicolumn{2}{|c|}{ Increasing population } \\
\hline & Coefficient & t-value & Coefficient & t-value \\
\hline \multicolumn{5}{|l|}{$\begin{array}{l}\text { Perceived consequences of population } \\
\text { decline on: }\end{array}$} \\
\hline Local tax level & $-0.30^{\star *}$ & 3.19 & $0.30^{* *}$ & 2.57 \\
\hline Local public service level & 0.08 & 0.57 & $-0.50^{\star *}$ & 3.44 \\
\hline Local space and nature & $0.39^{* *}$ & 3.65 & $-0.23^{*}$ & 1.90 \\
\hline \multicolumn{5}{|l|}{ Attitudes toward: } \\
\hline Immigration & $-0.63^{* *}$ & 7.18 & $0.28^{* *}$ & 2.78 \\
\hline Global warming & $0.36^{\star *}$ & 3.91 & $-0.28^{* *}$ & 2.67 \\
\hline \multicolumn{5}{|l|}{ Background variables } \\
\hline Age & 0.00 & 0.68 & 0.00 & 0.81 \\
\hline Sex $($ male $=0)$ & 0.03 & 0.26 & $-0.58^{* *}$ & 3.74 \\
\hline Years of education & 0.04 & 0.85 & -0.01 & 0.24 \\
\hline Income adequacy & -0.01 & 0.13 & -0.06 & 0.56 \\
\hline Religiosity & $0.22^{\star *}$ & 3.06 & 0.00 & 0.03 \\
\hline Population density, place of residence & $-0.34^{\star *}$ & 6.47 & $0.12^{*}$ & 2.00 \\
\hline Province of decline $(\mathrm{no}=0)$ & -0.35 & 1.41 & 0.36 & 1.77 \\
\hline Constant & $-2.08^{\star *}$ & 2.23 & 0.02 & 0.02 \\
\hline Pseudo $\mathrm{R}^{2}$ & \multicolumn{4}{|c|}{0.08} \\
\hline
\end{tabular}

Note: Absolute $t$ values are stated in parentheses. ${ }^{*}$ Significant at $p<0.05$. ${ }^{\star *}$ Significant at $p<0.01$.

${ }^{12}$ The question of the extent to which these anti-immigration opinions are associated with actual individual experiences of crime, or with other factors, such as stereotypes, is beyond the scope of this paper. 


\section{Background factors}

Thus far we have not discussed the role of background variables in the explanation of population size preferences. At this stage of the paper, however, it may be interesting to consider these variables. If we compare the models across the different geographical levels, a number of observations can be made about the background factors in the various models. First, women are less in favor of population increases at the local and national levels than men. Second, among the supporters of population decline at the local and national levels, no clear differences can be found as a function of age, sex, or education. Third, the population density of the place of residence is highly influential on the local population preference, and, to a lesser extent, on the national population preference. People living in rural areas are clearly more in favor of population growth and less in favor of population decline than urban dwellers. In addition, respondents living in provinces that have already experienced a drop in population numbers in the last decade oppose a further decline at the local level. It is remarkable that the role religion plays in people's lives is so apparent in their population preferences. Proponents of population decline are generally less religious than those favoring the status quo or population growth. It remains unclear, however, what train of thought is behind this divergence among the Dutch population. The link between religiosity and population preference tends to be in line with studies showing that those with strong religious views have more conservative positions on family planning, opposing birth control options like contraception or abortion (for an overview, see McQuillan 2004). But a more concrete reason may well be the fact that, within the Dutch system of church financing, churches depend to a great extent on their membership numbers. Because the viability of many Dutch churches is in danger in small rural villages, as well as in aging cities, we would not expect members of church parishes to support population decline.

\section{Population policy preferences}

It is natural to pose the question of how population size preferences impinge on the population policy stance of citizens. Liberal governments have a tradition of not interfering in the freedom to choose with respect to number of children, and it is of some interest to see how this policy stance changes under the circumstances of population decline. Based on the assumption that collective choice is a reflection of individual choice and support, it seems reasonable to ask citizens whether they agree with certain population policy choices. In Table 5 we report findings from questions on whether population decline should be counteracted by either a pronatalistic policy, or by increasing the level of immigration. To see how the level of agreement differs across citizens with different population size preferences - increase, stationarity, or declinewe have disaggregated the policy preferences by these categories. The results show that 
the Dutch are lukewarm with respect to these policies for counteracting population decline. Only $13 \%$ of the respondents support pronatalistic policies, and just $5 \%$ of the Dutch support the option of encouraging immigration.

Table 5: Level of agreement with policy proposals to counteract population decline by increasing fertility and immigration

\begin{tabular}{lrrrr}
\hline & & \multicolumn{3}{c}{$\begin{array}{c}\text { Population size preference } \\
\text { of respondents (in percentages): }\end{array}$} \\
\cline { 3 - 5 } & Total & Increase & Stationarity & Decline \\
\hline "When the population declines, the & & & & \\
fertility rate should be stimulated" & & & 37 & 63 \\
Disagree & 44 & 22 & 49 & 31 \\
Neutral & 13 & 47 & 14 & 6 \\
Agree & 100 & 100 & 100 & 100 \\
Total & & & & \\
"When the population declines, & & & 55 & 75 \\
immigration should be stimulated" & 60 & 35 & 40 & 21 \\
Disagree & 35 & 48 & 5 & 4 \\
Neutral & 5 & 17 & 100 & 100 \\
Agree & 100 & 100 & & \\
Total & & & & \\
\hline
\end{tabular}

Source: NIDI survey on population decline (2009). N = 2039

Of the two policy options, the immigration policy option is clearly less popular than the fertility option. This bias is perhaps most clearly illustrated by looking at the supporters of a population increase. The pronatalistic option has more supporters than opponents ( $41 \%$ versus $22 \%$ ), whereas the immigration option has more opponents than advocates $(35 \%$ versus $17 \%)$. In short, what the supporters of growth want is indigenous population growth, and not imported growth.

\section{Conclusion and discussion}

Population decline generally inspires fear in policymakers, and it is often associated with economic or cultural decline. Such an attitude may seem paradoxical if viewed from an historical perspective: in the 1970s and 1980s, many a population conference was dominated by alarmist messages about the deleterious consequences of excess 
van Dalen \& Henkens: Who fears and who welcomes population decline?

population growth (cf. Schindlmayr 2004). Thus, we would expect that population decline would be seen as a positive development. However, steeply declining populations in some European countries or regions have led to (again) alarmist voices within the halls of government. It is unfortunate that the voices and feelings of citizens living in regions experiencing population decline are often neglected in reflections on the population debate.

The present paper has tried to bring balance into the story of population decline by listening to the voices of citizens who experience it. The bottom line of this story is that population decline is certainly not always met with fear-it is even welcomed by some. The preference for population decline is most clear at the global level, but as soon as the phenomenon of decline moves closer to home, the preference becomes less pronounced and switches to the status quo. This is an important result, since it might suggest that, to a certain extent, population size preferences may be subject to what is generally known as the "not-in-my-backyard" (NIMBY) syndrome. For example, it is a well-established fact that people display this syndrome regarding the construction of waste sites: that is, people may support a plan to build a waste site, but they do not want it located in their backyard. Geographic proximity is a universal factor in understanding NIMBY conflicts (Dear 1992).

Establishing the extent to which attitudes toward population decline are subject to a true NIMBY effect is, of course, extremely difficult, because population preferences may be based in part on real concerns for the public interest, and not just on selfinterest. When asked about population size preferences within the Netherlands, citizens may realize that a population decline in their own backyards could threaten local welfare, and they may therefore opt for either an increasing population $(11 \%)$, or stationarity (75\%). At the national level, $31 \%$ would like the population to decline, and this decline is perceived as being accompanied by non-material welfare gains (improved environment), as well as material welfare losses (tax increases, economic stagnation). Apparently, respondents place a greater weight on non-material gains than on material losses in expressing a preference for a decline. Our study shows that materialistic considerations (e.g., taxes, level of public services, economic growth potential) are visible at the local and national levels. Non-materialistic motives are present at both geographic levels, although at the national level people seem to see more benign consequences of population decline than at the local level. At this point, the stated preferences of respondents are affected by their perceptions of how population decline may affect the quality of nature and the amount of space, and by their concerns about global warming. In addition to these driving forces, it appears that the attitude toward immigrants is a very strong determinant of preferences at the local and national levels: the arrival of new immigrants seems to generate greater fear than the prospect of population decline. The more people perceive immigration to be a 
disruptive force in society, the less likely they are to be in favor of population growth (or the more likely they are to favor population decline).

Many European regions and their governments are facing difficult policy dilemmas in dealing with the size and structure of their population. In the post-World War II era, governments could abstain from any form of policy intervention as populations seemed to grow steadily. Now, as the natural increase of regions falters, local governments fall back on strategies that are aimed at stimulating local growth, even if doing so harms the growth of neighboring regions. However, these policies are not in line with the preferences of citizens: there is only weak support for policy initiatives aimed at increasing the population at both the local and the national levels. This is particularly true for policies intended to encourage international migration. Furthermore, it appears that citizens have a far more nuanced assessment of population decline than was previously believed. Our study suggests that people are well aware of the potential economic disadvantages of population decline, but they can also see the potential non-material benefits of population reductions. Thus, local and national governments might learn an important lesson from their own citizens and view population decline in a balanced manner.

Population change has material and non-material consequences. Because governments have been strongly focused on the material implications, they have been trying to correct the decline by means of conventional population policies, such as stimulating fertility. However, governments, especially at the local level, may be better advised to face the facts of decline instead of trying to reverse population developments that seem to be largely inevitable. As Reher (2007) made clear in his thought-provoking essay on long-run population decline, "the decades ahead for much of the world will lead us into mostly uncharted territory that bears few similarities with past periods of population decline." Listening to the voice of citizens may help in exploring this uncharted territory.

\section{Acknowledgements}

Constructive comments by Douglas Hershey and three anonymous reviewers are gratefully acknowledged. 
van Dalen \& Henkens: Who fears and who welcomes population decline?

\section{References}

Bisin, A., Patacchini, E., Verdier, T., and Zenou, Y. (2011). Ethnic identity and labour market outcomes of immigrants in Europe. Economic Policy 26(65): 57-92. doi:10.1111/j.1468-0327.2010.00258.x.

Bongaarts, J. (2004). Population aging and the rising cost of public pensions. Population and Development Review 30(1): 1-23. doi:10.1111/j.17284457.2004.00001.x.

Borjas, G.J. (1995). The economic benefits from immigration. Journal of Economic Perspectives 9(2): 3-22

Coleman, D. and Rowthorn, R. (2011). Who's afraid of population decline? A critical examination of its consequences. Population and Development Review 37(Suppl. s1): 217-248. doi:10.1111/j.1728-4457.2011.00385.x.

De Jong, A. and Garssen, J. (2009). Regionale trends in bevolking en huishoudens. In : Van Nimwegen, N. and Heering, L. (eds.). Van groei naar krimp. Een demografische omslag in beeld. Amsterdam: KNAW Press: 59-85.

Dear, M. (1992). Understanding and overcoming the NIMBY syndrome. Journal of American Planning Association 58(3): 288-300. doi:10.1080/ 01944369208975808 .

Eichholtz, P.M.A. and Lindenthal, T. (2007). Demographics, human capital, and housing demand. Maastricht: Maastricht University, Department of Finance (working paper).

Geys, B., Heinemann, F., and Kalb, A. (2008). Local governments in the wake of demographic change: Evidence from German municipalities. FinanzArchiv: Public Finance Analysis 64(4): 434-457. doi:10.1628/001522108X397642.

Glaeser, E.L. (1998). Are cities dying? Journal of Economic Perspectives 12(2): 139160.

Haartsen, T. and Venhorst, V. (2010). Planning for decline: Anticipating on population decline in the Netherlands. Tijdschrift voor Economische en Sociale Geografie 101(2): 218-227. doi:10.1111/j.1467-9663.2010.00597.x.

Hardin, G. (1968). The tragedy of the commons. Science 162(3859): 1243-1248. doi:10.1126/science.162.3859.1243.

Jacobs, J. (1969). The economies of cities. New York: Random House. 
Keynes, J.M. (1937). Some economic consequences of a declining population. Eugenics Review 29(1): 13-17.

Krugman, P. (1991). Increasing returns and economic geography. Journal of Political Economy 99(3): 483-499. doi:10.1086/261763.

Krugman, P. (1998). Space: The final frontier. Journal of Economic Perspectives 12(2): 161-174.

Lucas, R.E.Jr. (1988). On the mechanics of economic development. Journal of Monetary Economics 22(1): 3-42. doi:10.1016/0304-3932(88)90168-7.

Mankiw, N.G. and Weil, D.N. (1989). The baby boom, the baby bust, and the housing market. Regional Science and Urban Economics 19(2): 235-258. doi:10.1016/0166-0462(89)90005-7.

Marshall, A. (1920). Principles of economics. London: MacMillan.

McQuillan, K. (2004). When does religion influence fertility? Population and Development Review 30(1): 25-56. doi:10.1111/j.1728-4457.2004.00002.x.

NIDI (2009). NIDI survey on population decline. The Netherlands: Netherlands Interdisciplinary Demographic Institute (NIDI).

Reher, D.S. (2007). Towards long-term population decline: A discussion of relevant issues. European Journal of Population 23(2): 189-207. doi:10.1007/s10680007-9120-z.

Schindlmayr, T. (2004). Explicating donor trends for population assistance. Population Research and Policy Review 23(1): 25-54. doi:10.1023/ B:POPU.0000019914.38253.5a.

Stark, L. and Kohler, H.-P. (2002) The debate over low fertility in the popular press: A cross national comparison, 1998-1999. Population Research and Policy Review 21(6): 535-574. doi:10.1023/A:1022990205200.

Stavins, R.N. (2011). The problem of the commons: Still unsettled after 100 years. American Economic Review 101(1): 81-108. doi:10.1257/aer.101.1.81.

Stiglitz, J.E. (2000). Economics of the public sector. New York: Norton \& Co.

Teitelbaum, M.S. and Winter, J.M. (1985). The fear of population decline. New York: Academic Press.

Teitelbaum, M.S. and Winter, J.M. (1998). A question of numbers - High migration, low fertility and the politics of national identity. New York: Hill \& Wang. 
van Dalen \& Henkens: Who fears and who welcomes population decline?

van Dalen, H.P. and Henkens, K. (2005). The rationality behind immigration policy preferences. De Economist 153(1): 67-83. doi:10.1007/s10645-004-7130-3.

van Dalen, H.P. and Henkens, K. (2007). Longing for the good life: Understanding emigration from a high-income country. Population and Development Review 33(1): 37-66. doi:10.1111/j.1728-4457.2007.00158.x.

van Dalen, H.P., Henkens, K., Hendrikse, W., and Schippers, J.J. (2010). Do European employers support later retirement? International Journal of Manpower 31(3): 360-373. doi:10.1108/01437721011050620.

Van Duin, C., and Garssen, J. (2011). Bevolkingsprognose 2010-2060: Sterkere vergrijzing, langere levensduur. Bevolkingstrends: 16-23.

Wicksell, K. (1914). Can a country become underpopulated? Ekonomisk Tidskrift 16: 195-208. (translated and reprinted in Population and Development Review 2008, 34: 347-355). 


\section{Appendix: Properties of scale variables}

\section{Table A1: Scale characteristics, psychometric properties and wording of survey items}

\begin{tabular}{|c|c|c|}
\hline Scale/Variable Name and Source & Items and Response Format & Scale Properties \\
\hline $\begin{array}{l}\text { Local public service level } \\
\text { 2-item scale. A single score for this } \\
\text { measure was constructed by } \\
\text { calculating an unweighted mean. } \\
\text { Higher scores correspond to further } \\
\text { increases. }\end{array}$ & $\begin{array}{l}\text { What do you expect will be the } \\
\text { consequence of population decline in your } \\
\text { place of residence for: (1) number of } \\
\text { shops; (2) public amenities (like schools, } \\
\text { swimming pools, etc.) ( } 1=\text { decrease } \\
\text { strongly; } 2 \text { = decrease; } 3 \text { =stay the same; } \\
4 \text { = increase; } 5 \text { = increase strongly). }\end{array}$ & $\alpha=0.71$ \\
\hline $\begin{array}{l}\text { National economic growth potential } \\
\text { 2-item scale. A single score for this } \\
\text { measure was constructed by } \\
\text { calculating an unweighted mean. } \\
\text { Higher scores correspond to further } \\
\text { increases. }\end{array}$ & $\begin{array}{l}\text { What do you expect will be the } \\
\text { consequence of population decline for the } \\
\text { Netherlands for: (1) economic growth; (2) } \\
\text { innovation level ( } 1=\text { decrease strongly; } 2 \\
=\text { decrease; } 3 \text { =stay the same; } 4 \text { = } \\
\text { increase; } 5 \text { = increase strongly). }\end{array}$ & $\alpha=0.61$ \\
\hline $\begin{array}{l}\text { Attitude toward immigration } \\
\text { 3-item scale. A single score for this } \\
\text { measure was constructed by } \\
\text { calculating an unweighted mean. } \\
\text { Higher scores correspond to higher } \\
\text { support. }\end{array}$ & $\begin{array}{l}\text { What is your evaluation of the extent to } \\
\text { which the Dutch government serves the } \\
\text { public interest with respect to: the } \\
\text { integration of immigrants? (1=very } \\
\text { negative; } 2 \text { = negative; } 3 \text { =neutral; } 4= \\
\text { positive; } 5 \text { = very positive); and To what } \\
\text { extent do you agree with the following } \\
\text { statements? (1) The growth in the number } \\
\text { of foreigners contributes to crime and } \\
\text { terrorism; (2) The multicultural society is } \\
\text { an asset to Dutch culture (1= completely } \\
\text { disagree; } 2 \text { = disagree; } 3=\text { neither agree } \\
\text { nor disagree; } 4=\text { agree; } 5=\text { completely } \\
\text { agree). }\end{array}$ & $\alpha=0.75$ \\
\hline
\end{tabular}


van Dalen \& Henkens: Who fears and who welcomes population decline?

\section{Table A1: (Continued)}

\begin{tabular}{lll}
\hline Scale/Variable Name and Source & Items and Response Format & Scale Properties \\
\hline Attitude toward global warming & To what extent do you agree with the & $\alpha=0.67$ \\
4-item scale. A single score for this & following statements? (1) We must \\
measure was constructed by & choose for the environment even though \\
calculating an unweighted mean. & this may harm economic growth; (2)I am \\
Higher scores correspond to higher & very worried about global warming; (3) \\
& The extinction of animal species should \\
& be combated by all means; (4) All the \\
& news about global warming are highly \\
& exaggerated (1= completely disagree; $2=$ \\
& disagree; 3=neither agree nor disagree; \\
& 4=agree; 5= completely agree). \\
\hline
\end{tabular}

$\mathrm{N}=2035$ 